\title{
The Impact of Monetary Policy on the Equity Market
}

\author{
Simin Hojat \\ Alpha Beta Investment Research, LLC \\ Mohammad Sharifzadeh \\ Walden University
}

\begin{abstract}
The problem is that prior studies examining the impact of monetary policy instruments on the equity market have produced mixed results. The purpose of this study was to determine the impact of changes in money supply (M2), federal funds rate (FFR), and federal funds futures on the expected rate of returns of publicly traded companies. We developed and tested a multifactor capital asset pricing model and applied regression methodologies suitable for panel data analysis to analyze the data. The multiple regression results showed positive moderation effect of M2, and negative moderation and mediation effects of FFR and federal funds futures on the expected rate of returns of publicly traded companies. The socioeconomic implication of these findings is that the Federal Reserve decisions on changing M2 is not influenced by changes in the equity prices, but changes in the equity prices are a signal for the Federal Reserve to adjust its decision on changing the FFR.
\end{abstract}

Keywords: monetary policy, equity market, CAPM, moderation effect, mediation effect

\section{Introduction}

The conventional goals of monetary policy are price stability, optimal employment, and sustained economic growth. However, the impact of monetary policy on the economy takes place through the broad channel of financial markets, specifically through the equity market (Bernanke \& Kuttner, 2003). Monetary policy leads to reallocation of resources in the economy through influencing investors' return expectations and their buy and sell decisions in the equity market. Therefore, knowledge of how monetary policy affects the equity market is essential for understanding the way monetary policy impacts the broader economy. The problem is that prior studies examining the impact of monetary policy instruments on the equity market have produced mixed results. In particular, other researchers did not cover all the changes that have occurred in the financial market, specifically in the equity market since the 2007-2008 financial crisis. The purpose of this study was to determine the impact of changes in money supply (M2), federal funds rate (FFR), and federal funds futures (FFF) on the expected rate of returns of publicly traded companies. The novelty of our research is that it is conducted within the theoretical framework of capital asset pricing model (CAPM). The findings are in conformity with the view that the response of the equity market to the Federal Reserve's (the Fed's) monetary policy has changed since the Fed started to implement an unconventional monetary policy after the crisis of 2007-2008.

The CAPM is the most referenced theory that tries to explain the relationship between risk and required rate of return and thus provides a conceptual method to determine the most important component of the asset valuation problem. The CAPM, which was independently developed by Sharpe (1964), Linter (1965), and Mossin (1966), makes certain assumptions about the behaviors of 
the investors and about the working of the capital market and on the basis of those assumptions derives a specific linear relationship between required rate of return and risk-a relationship that, according to CAPM, should hold for every individual asset or any combination of individual assets in order for the capital market to be in equilibrium. The basic tenet in the CAPM is that the reason why rates of return of individual stocks covary with one another is because the rate of return of every stock or any portfolio of stocks varies with a common factor, and that common factor is the rate of return of the overall asset market. The overall market is the portfolio of all risky assets, in which every asset is weighted by the dollar market value of that asset relative to total market values of all assets. The single factor CAPM is, therefore, expressed as per Equation 1:

$$
R R_{j}-R F R=\beta_{j}\left(M R_{t}-R F R\right),
$$

where $R R_{j}=$ rate of return on security $j, R F R=$ risk free rate, $M R=$ rate of return on the overall equity market, and $\beta_{j}=$ systematic risk of security $j$.

The problem with CAPM is that it condenses all macroeconomic variables, including the monetarypolicy-related variables, into one single variable: the overall equity market rate of return. This approach hides the distinct impacts of some significant macro- and company-specific risk factors in determining investors' required rate of returns in the equity market.

In this study, a multifactor CAPM containing five risk factors, three of which are monetary-policyrelated factors, is proposed and tested against empirical data to provide a better explanation of the factors that determine investors' required rates of return. Specifically, we examine the relationships between change in M2, FFR, and FFF on the investors' required rate of returns while controlling for the rate of return of the whole equity market and size of the sampled companies.

\section{Literature Review}

\section{Monetary Policy Instruments}

The impact of change in M2 on equity prices has been widely researched by economists (Cooper, 1974; Pesando, 1974; Rogalski \& Vinso, 1977). It is argued that an increase in M2 might add to the liquidity that is available to purchase securities and that would result in higher prices for stocks (Hamburner \& Kochin, 1972; Chen, 2007). However, it is now documented that M2 changes affect stock prices by changing investors' expectations about future policy of the Fed, implying that the that stock markets are forward looking (Bernanke \& Kuttner, 2003); similar results were obtained in our study.

The role of FFR as a measure of monetary policy expectations has been demonstrated by economists such as Bernanke and Blinder (1992) and Cook and Hahn (1989). These studies indicate that FFR changes affect asset prices. Thorbecke (1997) used event study methodology for the period 1987-1994 and found that the U.S. equity index reacted significantly to changes in the FFR, specifically on days when such changes took place (see also Patelis, 1997). Further research found that the part of FFR changes that really affect equity prices is the unexpected or surprised components of the change and not the part that was already expected by the market and was included in investors' calculations. The unexpected part of FFR changes, or what has become known as monetary policy shocks, was tested by Krueger and Kuttner (1996), Rudebusch (1998), and Brunner (2000), who were among the first to explore this approach, and many others have subsequently followed their lead.

A variety of financial market instruments have been tested in predicting the future path of monetary policy and some indicated that FFF contracts dominate all the other securities in forecasting monetary policy at horizons up to 6 months (Gürkaynak, Sack, \& Swanson, 2007). Kuttner (2000) estimated the effect of changes in Fed policy on a spectrum of market interest rates, using FFF data 
to distinguish anticipated from unanticipated changes in the target rate. The main finding of this report was the existence of a strong and robust relationship between surprise policy actions and market interest rates. Kuttner (2001) conducted event studies based on higher frequency observations on daily data and analyzed how equity markets react to monetary policy. He found that on the day of announcements, markets react mostly not to the announcements per se, but to their unexpected component that is not already priced into the market.

Bernanke and Kuttner (2003) derived monetary policy shocks through measures of market expectations obtained from FFF contracts. Further, Bernanke and Kuttner (2003) distinguished between expected and unexpected policy actions. They stated that anticipated policy actions are due to changes in economic outlook and they are already incorporated in investors' calculation of expected returns because stock market is forward looking. Unanticipated policy actions are not reflected in the equity prices yet, and they found FFF is a good measure of the surprise rate change. Bernanke and Kuttner (2003) found that the equity market reacts fairly strongly to the surprise FFR changes and little, if at all, to "the component of federal funds rate changes that are anticipated by market participants" (p. 2). Bernanke and Kuttner (2003) made an attempt to find out whether monetary policy affects stock values through its effects on real interest rates, expected future dividends, or expected future stock returns. The results showed that the reaction of equity prices to monetary policy is, for the most part, not directly attributable to policy's effects on the real interest rate.

Contrary to most of the research, which used monetary policy as exogenous factor in their model, Rigobon and Sack (2003) used monetary policy as endogenous factor and they showed that monetary policy has an endogenous reaction to the asset prices. In other words, the relationship between asset prices and monetary policy goes both ways. Our findings confirm this proposition. Monetary authorities constantly monitor the equity market and consider its development in their policy decisions (see Yellen, 2015). Rigobon and Sack (2003) showed that monetary policy reacts to stock market developments because of the potential impact of the stock market movements on aggregate demand in the economy.

\section{Firm Heterogeneous Response to Monetary Policy}

Companies' equities react differently to monetary policy; the company-specific factors most researched are company size and financial constraints. Fama and French $(1992,1996)$ confirmed that size of the firms affect their reaction to the systematic risk. Size and other firm- and industryspecific features create additional risk for each specific equity. Equities of the small and financially constrained firms are more vulnerable to monetary policy shocks than equities of large and less financially constrained firms (Fama \& French, 2004). Based on this evidence, Fama and French $(1993,1996)$ proposed a three-factor CAPM that included size and other firm-specific features. The same results obtained by Thorbecke (1997) and Perez-Quiros and Timmermann (2000) that the response of stock returns to monetary policy is stronger for small firms were shown in our model.

Ehrmann and Fratzscher (2004) indicated that the firms included in the S\&P 500 stock index react in a highly heterogeneous fashion to U.S. monetary policy shocks because of industry-specific and firm-specific features. Firms in the cyclical industries react two to three times stronger to U.S. monetary policy than firms in noncyclical industries. They also concluded that financially constrained firms respond more to monetary policy than less constrained ones.

\section{Asset Mispricing}

Bernanke, Gertler, and Gilchrist (1999) were the first to note the issue of asset mispricing and monetary policy. They included an exogenous element as a symbol for bubbles in their financial 
accelerator model. They found that the bubble exists, but they concluded that it decays over time, and when it bursts, the asset prices go back to the fundamental value. Around the same time, Cecchetti, Genberg, Lipsky, and Wadhwani (2000) researched bubbles and concluded that monetary policy should react to the asset mispricing and correct the cycles in the asset market. This view that is known as leaning-against-the-wind theory in the literature has become subject to a many controversies over the years. Bernanke and Gertler (2001) opposed the leaning-against-the-wind theory on the basis of hard practical implications of this theory. They stated that the nature of bubbles may differ from each other, and there should be a distinction between asset price movements that are caused by a change in economic activity and the price changes that are the result of noise trading.

Greenspan (1995) refuted the leaning-against-the-wind theory based on irrational exuberance that escalates asset values out of proportion with economic reality. Greenspan (2002) stated that it is difficult to distinguish between asset price changes due to economic activity and the movements due to exuberance. Gwilym (2013) highlighted the difference between asset mispricing targeting and historical trend targeting. He is in favor of lean-against movements in asset prices away from their trend but not against the mispricing of assets. Gwilym (2013) noted that there is a danger to the target asset mispricings by central banks because "the effects of a mispricing policy are counterintuitive and a leaning against the wind policy exacerbates the effects of behavioral biases" (p. 268). Blinder (2010) distinguished credit-fueled bubbles and equity-type bubbles. In the case of equity type of bubbles, Blinder suggested that it is justifiable to do the so called mop up after the burst of the bubble, but the central bank should combine regulatory instruments and interest rates manipulation to limit credit-based bubbles. The existence of asset price booms and bursts in the market, the closeness of asset price movements in the equity market with systematic risk and macro variables has turned the pendulum of opinions in favor of leaning-against-the-wind monetary policy in order to offset asset price bubbles (Gwilym, 2013). In fact, the Fed always considers economic circumstances in their monetary policy decisions (Yellen, 2015).

\section{Monetary Policy After 2008}

In the aftermath of the 2008 financial crisis, major central banks drove short rates to what was effectively the zero lower bound, which actually disabled the efficacy of monetary policy. "It is not a happy circumstance for central banks, yet monetary policy is not impotent at the zero lower bound" (Rogers, Scotti, \& Wright, 2012, p. 36). After reaching the effective lower bound for the FFR in late 2008, the Fed turned to "two unconventional policy tools-quantitative easing programs and increasingly explicit forward-leaning guidance for the future path of the federal funds rate" (Engen, Laubach, \& Reifschneider, 2015, p. 2). The goal of these unconventional policy actions was to improve overall financial conditions in the economy, including bolstering of corporate equity prices. There are quite a number of studies on the effect of unconventional monetary policy on asset prices (see Doh, 2010; Gagnon, Raskin, Remache, \& Sack, 2011; Rosa, 2012; Meaning \& Zhu, 2011; Neely, 2010; Krishnamurthy \& Vissing-Jorgenson, 2011; Swanson, 2011; Wright, 2012). Rogers et al. (2014) conducted a research on the effect of unconventional monetary policy on asset prices and concluded that the expansionary monetary policy shocks significantly raises domestic stock prices in the United States (see also Giannone, Lenza, Pill, \& Reichlin, 2011; Lenza \& Reichlin, 2010).

However, the shift of monetary policy of the Fed toward unconventional monetary policy since 2008 "has changed the relationship between equity prices and Fed policy" (Berge \& Guangve, n.d, p. 6). The large asset purchases by the Fed put a downward pressure on term premium that eased financial markets and helped the economic recovery. Moreover, and most important for our analysis in this article, was the increasingly intense use of forward guidance by the Fed and its effect on equity market. The forward guidance, which became an important aspect of the Federal Open Market Committee (FOMC) decision making, was conveyed to the economy through what was called 
the Fed Announcement. In fact, this was the part of monetary policy that reveals information about the likely future path of the FFR. This preguided policy would, in fact, reduce the effect of unforeseen changes of monetary policy or monetary shocks in the economy (Doh \& Connolly, 2013).

FOMC announcements convey different messages based on the wording of the message, and in further analysis, investors could distinguish between what is called the path factor and what is called the target factor (Gürkaynak et al., 2007). The target factor that explains the movements of the future rates along the entire yield curve is interpreted as the surprise component of a change in the current level of the FFR. The target factor is associated with the economic outlook and might arise because FOMC's forward guidance about the future monetary policy depends on the economic outlook (Blanchard, 2012). The path factor, on the other hand, "captures information that market perceives in FOMC announcements about the future path of the target rate beyond what is captured by the target factor" (Woodford, 2012, p. 85). In other words, announcements have two components, the expected and the unexpected or the surprise component and asset price changes are induced by the surprise part of the FOMC announcement that conveys new information about the future path of the Fed's policy, not to what financial markets have already anticipated (Doh \& Connolly, 2013). Thus, (a) investors should identify and distinguish the surprise part of the announcements from the expected part; (b) because forward guidance is conveyed to the public through words, it must be quantified to be usable for investors' calculation and decision making; and (c) the surprise part of the announcements is related to the economic outlook and this makes the target rate a possibility, contingent upon future outlook, not a promise (Blanchard, 2012; Woodford, 2012; Yellen, 2015).

As a proxy for the surprise part of the announcement, researchers typically use the changes in the price of interest rate futures contracts, such as FFF contracts or Eurodollar futures contracts. Economic reasoning is that price of futures contracts that reflects the future path of FFR is related to the changes in the private sector's policy expectations, and these changes are good indicator of the surprise component in policy guidance. In fact, forward guidance is aimed at affecting the private sector's expectations about the future path of the FFR, as well as affecting asset prices (Doh \& Connolly, 2013).

We believe that the unpredicted response of equity market to the Fed's policy needs more attention if Fed monetary policy is to be relevant again in stabilizing the financial market and achieving the double goal of controlling inflation and unemployment rate within the neutral rate. However, scientific research is sparse and there is a gap that has to be filled. The literature review indicates there is a gap in the literature and there is minimal research examining the relationship between market expectation of monetary policy, as reflected in the FFF, and the equity market in recent years. We conducted this scientific research within the theoretical framework of CAPM to fill the gap; this is a novel approach rarely used before.

\section{Methodology}

This study is quantitative with longitudinal research design. We used existing panel data (a time series of cross sections) to examine the relationship between the independent and dependent variables. We collected a time series of cross-section data on the realized rate of return on the equity and the size of a sample of publicly traded U.S. corporations as well as data on the overall U.S. stock market rate of return, the change in M2, change in the FFR, and change in FFF, over the 10-year period 2005-2015. The scope of this research was confined to all publicly traded companies in the U.S. equity market. The variables of the units of analysis were retrieved from the stock market databases and the Fed website. 


\section{Panel Data Design}

A panel dataset consists of observations on multiple units (entities, companies, individuals, etc.), which is the unit that is observed at two or more points in time. The general model framework for regression analysis using panel data approach is

$$
Y_{j t}=\beta_{0 j}+\beta_{j} X_{j t}+\varepsilon_{j t},
$$

where, $j=1,2, \ldots$ are individual items in the cross sections; $t=1,2,3, \ldots$.represent time periods; $\beta_{0 j}=$ intercept for unit $j ; \beta_{j}=$ row vector of regression coefficients; $X$ is matrix of observations on individual items; and $\beta$ is the error term. The error tem has two dimensions, one for the units and one for the time.

The general model expressed in Equation 2 can take three possibilities (Beck, 2001):

1. Beck (p. 24) defined pooled regression without individual effects as follows: If $\beta_{0 j}$ contains only a constant term for all the units, that is individual units have the same intercept, then ordinary least squares (OLS) approach provides consistent and efficient estimates of the common $\alpha$ and the slope vector $\beta$, provided assumptions of OLS are met. In this model, both slopes and intercepts are the same for all units. The pooled regression model can be expressed as follows:

$$
Y_{j t}=\beta_{0}+\beta_{j} X_{j t}+\varepsilon_{j t} .
$$

2. In the fixed-effects model, each unit $j$ has its distinct intercept $\beta_{0 j}$, and each $\beta_{0 j}$ is a nonrandom constant. The OLS is applied to solve the regression equation by including $N-1$ dummy variables in the model which take values of 1 if $i=j$ and 0 if $i \neq j$. This model is often referred to as least squares dummy variables. The slope is the same for all units, and the intercepts differ according to cross-sectional units, or time, or both cross-sectional units and time. The fixed effect model can be expressed as

$$
Y_{j t}=\beta_{0 j}+\beta X_{j t}+\varepsilon_{j t} .
$$

3. In the random effects (RE) model (p. 26), it is assumed that each intercept $\beta_{0 j}$ contains a constant term, which is the same for all units, and a random term, which is different for each unit. So, the RE model would be as follows:

$$
Y_{j t}=\left(\beta_{0}+u_{j}\right)+\beta_{j} X_{j t}+\varepsilon_{j t} .
$$

Other variants of the random effect model include fixed intercept, random slope as shown in Equation 6 and random intercept-random slope as shown in Equation 7:

$$
\begin{array}{r}
Y_{j t}=\beta_{0}+\left(\beta_{j}+v_{j}\right) X_{j t}+\varepsilon_{j t} \\
Y_{j t}=\left(\beta_{0}+u_{j}\right)+\left(\beta_{j}+v_{j}\right) X_{j t}+\varepsilon_{j t} .
\end{array}
$$

The RE model is solved "using general least square (GLS) approach" (p. 27). 


\section{The Model}

The research question and hypotheses addressed in this study are about the significance of aforementioned five independent variables in predicting the dependent variable. The statistical methodology adopted for testing the hypotheses was multiple regression, as expressed in Equation 8:

$$
R R_{j t}=\beta_{0}+\beta_{1} M R_{t}+\beta_{2} S_{j}+\beta_{3} M S_{t}+\beta_{4} F F R_{t}+\beta_{5} F F F_{t}+\varepsilon_{j t},
$$

where, $R R_{j t}=$ rate of return on company's $j$ stock during year $t ; M R_{t}=$ rate of return on the overall stock market during year $t ; S_{j}=$ company's j size, a dummy variable 1 if the company is small cap and 0 if company is large cap; $M S_{t}=$ change in M2 during year $t ; F F R_{t}=$ change in the FFR during time $t ; F F F_{t}=$ change in FFF during period $t$; and $\beta_{j t}=$ regression residual. $R R_{j t}$ is calculated using Equation 9:

$$
R R_{j t}=\frac{P_{j t}-P_{j(t-1)}+D_{j t}}{P_{j(t-1)}},
$$

where $P_{j t}$ and $P_{j(t-1)}$ are price of company j stock in years $t$ and $(t-1)$, respectively, and $D_{j t}$ is the dividends paid by company $\mathrm{j}$ during year $t$.

\section{Population and Sample}

The target population included publicly trading companies in the United States whose securities are traded in the New York Stock Exchange or NASDAQ. The sampling frame chosen for this target population was the list of companies that constitute the Russell 1000 (large cap) and Russell 2000 Stock (small cap) indexes, which includes about $98 \%$ of the investable U.S. equity market (www.russell.com). We used stratified random sampling method for this study. The stratification was based on companies' market capitalization (size). Therefore, one third of the sample was taken from large-cap stocks and two thirds from small-cap stocks.

The sample period was from January 2005 to January 2015, and time-series data on the selected companies were collected for this period. This time period was chosen because (a) it provided the opportunity to test the effect of monetary policy on equity market for both pre- and post-2008 crisis, and (b) it covered the era of post financial crisis where general economic conditions were completely different.

To calculate minimum required sample size we used $G^{*}$ Power 3.1 software. We selected multiple linear regression, fixed model, single regression coefficient. Following their instructions on their manual $(G *$ Power 3.1, 2014) for a two-tailed test with medium effect size of 0.15 , five predictors, $\alpha=$ $5 \%$, and power $=95 \%$, the software gave us sample size of 89 . We selected 90 companies for ease of stratification. Therefore, our stratified sample consisted of 30 large cap corporations randomly drawn from Russell 1000 Stock Index companies and 60 small-cap corporations randomly drawn from Russell 2000 Stock Index companies. 


\section{Data Analysis}

\section{Descriptive Statistics}

There were 11 data sets on annual rate of return of the overall stock market (covering the period January 2005 through January $2015(M=10.04 \%, S D=17.54 \%$, and skewness $[\mathrm{SK}]=-1.47)$. For the same time period of 2005-2015, the annual rates of return of the 30 large companies were calculated, which gave rise to 330 large company annual rates of return $(M=13.99 \%, S D=45.33 \%, \mathrm{SK}=3.05)$. For the 60 small companies, there were 660 data sets on annual rates of return of small companies $(M=15.22 \%, S D=61.36 \%, \mathrm{SK}=5.98)$. These descriptive statistics are shown in Table 1.

Table 1. Descriptive Statistics for the Independent and Dependent Variables of Equation 12

\begin{tabular}{lcccc}
\hline & $N$ & $M$ & $S D$ & SK \\
\hline $\begin{array}{l}\text { Stock market rate of return (Russell 3000 stock } \\
\quad \text { index \%) }\end{array}$ & 11 & 10.04 & 17.54 & -1.47 \\
Large company stock rate of return (\%) & 330 & 13.99 & 45.33 & 3.05 \\
Small company stock rate of return (\%) & 660 & 15.22 & 61.36 & 5.98 \\
Change in money supply (\%) & 11 & 6.06 & 1.69 & -0.5 \\
Change in federal fund rate (\%) & 11 & -0.09 & 1.32 & -0.7 \\
Change in federal fund futures (\%) & 11 & 0.32 & 1.06 & 1.72 \\
\hline
\end{tabular}

Note. $S D=$ standard deviation; $\mathrm{SK}=$ skewness.

The results shown in Table 1 are consistent with the CAPM and with Markowitz's (1952) modern portfolio theory. According to CAPM and Markowitz's modern portfolio theory, in portfolio investments, there is a positive relationship between risk and return: more expected return comes with more risk. As can be seen in Table 1, the more realized historical portfolio returns, the higher the risk (as measured by standard deviation of returns). These results are also in line with Fama and French's (1992) findings, as discussed in the literature review. According to Fama and French (1992), small-capitalization stock portfolios have higher expected returns and higher risks as compared to large-capitalization portfolios, and the results in Table 1 are consistent with this proposition.

\section{Pooled Regression Results}

In a pooled approach to panel data analysis, it is assumed that individual units have the same regression intercept, and thus OLS is applied to find the common intercept and the regression coefficients. Results for the pooled regression approach are shown in Table 2.

Table 2. Multiple Regression Output for the Pooled Model

\begin{tabular}{lccccc}
\hline & $B$ & $S E B$ & $b$ & $p$ & VIF \\
\hline Constant & 14.22 & 9.08 & - & .118 & \\
Market rate of return (\%) & 1.03 & 0.15 & $0.32^{* * *}$ & .000 & 2.45 \\
Company size & 1.22 & 3.60 & $0.01^{*}$ & .035 & 1.00 \\
Money supply change (\%) & -1.51 & 1.26 & $-0.05^{n s}$ & .232 & 1.58 \\
Federal fund rate change (\%) & -8.35 & 3.54 & $-0.19^{n s}$ & .155 & 7.60 \\
Federal fund futures change (\%) & -7.00 & 4.92 & $-0.13^{n s}$ & .155 & 9.52 \\
\hline
\end{tabular}

Note. VIF = variance inflation factor; $n s=$ not significant. $R^{2}=0.112(p<.001)$.

${ }^{*} p<.05 .{ }^{* * *} p<.001$. 
Data analysis for the pooling approach indicates a significant overall relationship between independent variables taken together and the dependent variable $\left(R^{2}=11.2 \%, p<.001\right)$. However, market rate of return and company size are the only statistically significant predictors of companies' rates of return $(B=14.22, p<.001$ for market rate of return and $B=1.22, p<.05$ for company size). The other independent variables-M2, FFR change, and FFF change-all have $p$ values greater than .05 .

The finding that market rate of return is a significant predictor of companies' rates of return on equity is consistent with CAPM theory, and the finding that company size is a significant predictor of companies' rates of return on equity is consistent with Fama and French's (1992) findings. Because the code for the dummy variable company size was 0 for large companies and 1 for small companies and the regression estimate for the intercept $(B)$ was equal to 1.22 , the regression results indicate that small companies had, on average, $1.22 \%$ higher rates of return on equity as compared to large companies. This finding is consistent with the descriptive statistics reported in Table 1.

However, the findings that monetary-policy-related instruments, M2, FFR change, and FFF change are not significant predictors of companies' rates of return on equity are unexpected and are not supported by theory. Besides, high-variance inflation factors for the FFR change and FFF change point to the possibility of multicollinearity, which distorts the regression results. One method to address this problem, which is consistent with theory, is to treat the monetary-policy-related variables as moderator and mediator variables. According to CAPM, as posited by Sharpe (1964), the market rate of return embodies all macroeconomic factors, including monetary-policy-related instruments such as M2, FFR change, and FFF change. Therefore, in the next few subsections, we modify the pooled regression model and treat the monetary variables as moderator and then as mediator variables.

Moderation occurs when the moderating factor $(M)$ significantly affects the strength and direction of the relationship between the dependent variable $(Y)$ and the independent variable $(X)$. That means the interaction (combined) effect of $X$ and $M$ on $Y$ is statistically significant, which in turn implies that in the linear regression of $Y$ against $X$, the $\beta$ coefficient, is significantly different for different value ranges of $M$.

Mediation occurs when the relationship between outcome $(Y)$ and predictor $(X)$ can be explained through their relationship with the mediator $(M)$ variable.

Mediation is tested through three regression models, (a) a regression predicting the outcome $Y$ from the predictor variable $X$, (b) a regression predicting the mediator $M$ from the predictor variable $X$, and (c) a regression predicting the outcome $Y$ from both the predictor $X$ variable and the mediator $M$. (Field, 2013, p. 480)

For mediation to occur, the predictor variable $X$ must predict the outcome variable $Y$ less strongly in Model (c) than in Model (a).

SPSS software does not have a separate function for moderation and mediation analysis. However, there is a method to add these moderation and mediation features to the SPSS software. Following Field's (2013) instructions, we downloaded and installed the PROCESS software from Andrew F. Hayes's website, http://www.afhaynes.com, and a new tab was added to the SPSS regression menu for moderation and mediation analysis. With this added feature, it is possible to conduct moderation and mediation analysis by including in the model one moderator/mediator and one continuous independent variable at a time. 
M2 as the moderating variable.

The model with M2 as the moderator variable is expressed in Equation 10.

$$
R R_{t j}=\beta_{0}+\beta_{1} M R_{t}+\beta_{2} M S_{t}+\beta_{3} M R_{t} \times M S_{t}+\varepsilon_{t j}
$$

The SPSS output for moderation effect of M2 is reported in Table 3.

Table 3. The Effect of Change in M2 on the Relationship Between Market Rate of Return and the Companies' Rates of Return on Equity

\begin{tabular}{lccc}
\hline & $B$ & $S E B$ & $p$ \\
\hline Constant & 14.91 & 1.73 & $<.001$ \\
Money supply change (\%) & -1.57 & 1.17 & $>.05$ \\
Market rate of return & 0.73 & 0.16 & $<.001$ \\
Money Supply Change (\%) $\times$ Market & 0.38 & 0.22 & $<.05$ \\
$\quad$ Rate of Return (interaction effect) & & & \\
\hline
\end{tabular}

Note. $R=0.33, R^{2}=0.11(p<.001)$.

As can be seen from the results in Table 3, there is a significant positive moderation effect of M2 on the relationship between market rate of return and companies' rates of return on equity (for the interaction effect, $B=0.38, p<.05$ ). Moreover, the output of the Johnson-Neyman (1936) method indicates the following:

1. When the percentage change in M2 is low $(-1.69 \%$ or less when centered), there is nonsignificant positive relationship between market rate of return and companies' rates of return on equity, $B=0.08, t=0.15, p=.88$.

2. When the percentage change in $\mathrm{M} 2$ is at its mean value $(0.000 \%$ when centered), there is a significant positive relationship between market rate of return and companies' rates of return on equity, $B=0.73, t=4.5, p=.000$.

3. When the percentage change in M2 is high ( $1.69 \%$ when centered), there is a significant positive relationship between market rate of return and companies' rates of return on equity, $B=1.38, t=5.4, p=.000$.

These findings indicate that there is a positive relationship between market rate of return and rate of return on companies' equity at all levels of M2. However, the strength of the relationship between market rate of return and rate of return on companies' equity increases as the percentage change in M2 increases (because of the increasing value of regression coefficient $B$ ), and this relationship is not statistically significant when the percentage change in M2 is low.

M2 as the mediating variable.

The mediation model with M2 involves the following three regression equations:

$$
\begin{aligned}
& R R_{t j}=\beta_{0}+\beta_{1} M R_{t}+\varepsilon_{t j} \\
& M S_{t}=\beta_{0}+\beta_{1} M R_{t}+\varepsilon_{t j} \\
& R R_{t j}=\beta_{0}+\beta_{1} M R_{t}+\beta_{2} M S_{t}+\varepsilon_{t j} .
\end{aligned}
$$

The SPSS output for the mediation effect of M2 on the relationship between market rate of return and companies' rates of return on equity is shown in Table 4. 
Table 4. Regression Results for $M 2$ as the Mediator

\begin{tabular}{lcccc}
\hline Model & $B$ & $S E B$ & $p$ & $R^{2}$ \\
\hline $\begin{array}{l}\text { Total effect (mediator not } \\
\text { present, Equation 14) }\end{array}$ & 1.04 & 0.097 & $<.001$ & $0.105^{* * *}$ \\
$\begin{array}{l}\text { Direct effect (mediator is } \\
\text { present, Equation 16) }\end{array}$ & 1.04 & 0.097 & $<.001$ & $0.105^{* * *}$ \\
$\begin{array}{l}\text { Effect of predictor on } \\
\text { mediator (Equation 15) }\end{array}$ & -0.001 & 0.003 & $>.05$ & $0.0001^{n s}$ \\
\hline
\end{tabular}

Note. $n s=$ not significant.

$* * * p<.001$.

As shown in Table 4, market rate of return is a significant predictor of companies' rates of return on equity both when M2 is present in the equation (direct effect) and when M2 is not present in the regression equation (total effect), and in both cases, $10.5 \%$ of variations in the dependent variable is explained by variations of the independent variable(s), $R^{2}=10.5 \%$. However, per the regression results of Equation 11, the market rate of return is not a significant predictor of the M2 and very little variation of M2 is explained by variations of market rate of return, $R^{2}=0.01 \%$. This implies that there is no indirect effect of M2 on the relationship between market rate of return and companies' rates of return on equity-that is, M2 is not a mediator in this relationship. This result is also confirmed by Preacher and Kelley's (2004) kappa-squared test results, $\kappa^{2}=0.002$, for the indirect effect, 95\% bias-corrected and accelerated (BCa) confidence interval (CI) [0.000, 0.001]. The CI for $\kappa^{2}$ contains 0 , so there is no mediation effect of M2 on the relationship between market rate of return and companies' rates of return on equity.

The FFR as the moderating variable.

The model for the federal fund rate as the moderator variable is expressed in Equation 14.

$$
R R_{t j}=\beta_{0}+\beta_{1} M R_{t}+\beta_{2} F F R_{t}+\beta_{3} M R_{t} \times F F R_{t}+\varepsilon_{t j}
$$

The SPSS output for moderation effect the FFR is reported in Table 5.

Table 5. The Effect of Change in the Federal Funds Rate on the Relationship Between Market Rate of Return and the Companies' Rates of Return on Equity

\begin{tabular}{lccc}
\hline & $B$ & $S E B$ & $p$ \\
\hline Constant & 15.30 & 2.29 & $<.001$ \\
Federal fund rate (\%) & -3.69 & 2.69 & $>.05$ \\
Market rate of return & 1.07 & 0.16 & $<.001$ \\
Federal Fund Rate change (\%) $\times$ & -0.46 & 0.95 & $<.05$ \\
$\quad$ Market Rate of Return (interaction & & & \\
$\quad$ effect) & & & \\
\hline
\end{tabular}

Note. $R=0.33, R^{2}=0.11(p<.001)$. 
As can be seen from the results in Table 5, there is a significant negative moderation effect of change in the FFR on the relationship between market rate of return and companies' rates of return on equity $(B=-0.46, p<.05)$. Moreover, the output of the Johnson-Neyman (1936) method indicates the following:

1. When percentage change in the FFR is low ( $-1.32 \%$ or less when centered), there is significant positive relationship between market rate of return and companies' rates of return on equity, $B=1.13, t=8.34, p=.000$.

2. When percentage change in the FFR is at its mean value $(0.000 \%$ when centered), there is a significant positive relationship between market rate of return and companies' rates of return on equity, $B=1.07, t=6.81, p=.000$.

3. When percentage change in the FFR is high (1.32\% when centered), there is a significant positive relationship between market rate of return and companies' rates of return on equity, $B=1.01, t=4.05, p=.0001$.

These findings indicate that there is a positive relationship between market rate of return and rate of return on companies' equity at all levels of FFR. However, the strength of the relationship between market rate of return and rate of return on companies' equity decreases as the percentage change in the FFR increases (because of decreasing values of regression coefficient $B$ ) and this relationship is statistically significant at all levels of the FFR changes.

The FFR as the mediating variable.

The mediation model with the federal fund rate involves the following three regression equations:

$$
\begin{aligned}
& R R_{t j}=\beta_{0}+\beta_{1} M R_{t}+\varepsilon_{t j} \\
& F F R_{t}=\beta_{0}+\beta_{1} M R_{t}+\varepsilon_{t j} \\
& R R_{t j}=\beta_{0}+\beta_{1} M R_{t}+\beta_{2} F F R_{t}+\varepsilon_{t j} .
\end{aligned}
$$

The SPSS output for the mediation effect of the FFR on the relationship between market rate of return and companies' rates of return on equity is shown in Table 6.

Table 6. Regression Results for the Federal Funds Rate as the Mediator

\begin{tabular}{lcccc}
\hline Model & $B$ & $S E B$ & $p$ & $R^{2}$ \\
\hline $\begin{array}{c}\text { Total effect (mediator not } \\
\text { present, Equation 18) }\end{array}$ & 1.04 & 0.097 & $<.001$ & $0.105^{* * *}$ \\
$\begin{array}{c}\text { Direct effect (mediator is } \\
\text { present, Equation 20) }\end{array}$ & 1.16 & 0.11 & $<.001$ & $0.109^{* * *}$ \\
$\begin{array}{c}\text { Effect of predictor on } \\
\text { mediator (Equation 19) }\end{array}$ & 0.035 & 0.002 & $<.001$ & $0.212^{* * *}$ \\
\hline$* * * p<.001$. & & & &
\end{tabular}

As shown in Table 6, the market rate of return is a significant predictor of companies' rates of return on equity both when the FFR is present in the equation (direct effect) and when the FFR is not present in the regression equation (total effect). Moreover, when the FFR is present $10.9 \%$ of variations in the dependent variable is explained by variations of the independent variable(s), $R^{2}=$ $10.9 \%$ which is higher than the $R^{2}=10.5 \%$ for when the FFR is not included in the equation.

Furthermore, per regression results of Equation 15, the market rate of return is a significant predictor of the FFR and $21.2 \%$ of variations of the FFR is explained by variations of the market rate of return, $R^{2}=21.2 \%$. This implies there is a significant indirect effect of the FFR on the relationship between market rate of return and companies' rates of return on equity, that is, change in the FFR is 
a mediator in this relationship. This result is also confirmed by Preacher and Kelley's (2004) kappasquared test results, $\kappa^{2}=0.035$, for the indirect effect, 95\% BCa CI [0.003, 0.075]. The CI for $\kappa^{2}$ does not contain 0 , so there is a mediation effect of the FFR change on the relationship between market rate of return and companies' rates of return on equity.

FFF as the moderating variable.

The model with the FFF as the moderator variable is expressed in Equation 18.

$$
R R_{t j}=\beta_{0}+\beta_{1} M R_{t}+\beta_{2} F F F_{t}+\beta_{3} M R_{t} \times F F F_{t}+\varepsilon_{t j}
$$

The SPSS output for moderation effect of FFF is reported in Table 7.

Table 7. The Effect of Change in Federal Funds Futures on the Relationship Between Market Rate of Return and the Companies' Rates of Return on Equity

\begin{tabular}{lccc}
\hline & $B$ & $S E B$ & $p$ \\
\hline Constant & 13.62 & 2.08 & $<.001$ \\
Change in federal fund futures (\%) & 1.51 & 3.41 & $>.05$ \\
Market rate of return & 1.28 & 0.19 & $<.001$ \\
Federal Fund Futures change (\%) $\times$ & -0.09 & 0.08 & $<.05$ \\
$\quad$ Market Rate of Return (interaction & & & \\
effect) & & & \\
\hline
\end{tabular}

Note. $R=0.33, R^{2}=0.11(p<.001)$.

As can be seen from the results in Table 7, there is a significant negative moderation effect of change in FFF on the relationship between market rate of return and companies' rates of return on equity $(B=-0.09, p<.05)$. Moreover, the output of the Johnson-Neyman (1936) method indicates the following:

1. When percentage change in FFF is low $(-1.03 \%$ or less when centered), there is significant positive relationship between market rate of return and companies' rates of return on equity, $B=1.38, t=5.81, p=.000$.

2. When percentage change in $\mathrm{FFF}$ is at its mean value $(0.000 \%$ when centered), there is a significant positive relationship between market rate of return and companies' rates of return on equity, $B=1.28, t=6.54, p=.000$.

3. When percentage change in FFF is high $(1.06 \%$ when centered), there is a significant positive relationship between market rate of return and companies' rates of return on equity, $B=1.18, t=6.27, p=.0001$.

These findings indicate that there is a positive relationship between market rate of return and rate of return on companies' equity at all levels of FFF. However, the strength of the relationship between market rate of return and rate of return on companies' equity decreases as the percentage change in FFF increases (because of decreasing values of regression coefficient $B$ ), and this relationship is statistically significant at all levels of FFF changes. 
FFF as the mediating variable.

The mediation model with federal fund futures involves the following three regression equations:

$$
\begin{aligned}
& R R_{t j}=\beta_{0}+\beta_{1} M R_{t}+\varepsilon_{t j} \\
& F F F_{t}=\beta_{0}+\beta_{1} M R_{t}+\varepsilon_{t j} \\
& R R_{t j}=\beta_{0}+\beta_{1} M R_{t}+\beta_{2} F F F_{t}+\varepsilon_{t j} .
\end{aligned}
$$

The SPSS output for the mediation effect of FFF on the relationship between market rate of return and companies' rates of return on equity is shown in Table 8.

Table 8. Regression Results for Federal Funds Futures as the Mediator

\begin{tabular}{lcccc}
\hline Model & $B$ & $S E B$ & $P$ & $R^{2}$ \\
\hline $\begin{array}{l}\text { Total effect (mediator not } \\
\text { present, Equation 22) }\end{array}$ & 1.04 & 0.097 & $<.001$ & $0.105^{* * *}$ \\
$\begin{array}{l}\text { Direct effect (mediator is } \\
\text { present, Equation 24) }\end{array}$ & 1.18 & 0.137 & $<.001$ & $0.107^{* * *}$ \\
$\begin{array}{l}\text { Effect of predictor on } \\
\text { mediator (Equation 23) }\end{array}$ & -0.043 & 0.001 & $<.001$ & $0.492^{* * *}$ \\
$* * * p<.001$. & & & &
\end{tabular}

As shown in Table 8, the market rate of return is a significant predictor of companies' rates of return on equity both when FFF is present in the equation (direct effect) and when FFF is not present in the regression equation (total effect). Moreover, when FFF is present, 10.7\% of variations in the dependent variable is explained by variations of the independent variable(s), $R^{2}=10.7 \%$, which is higher than the $R^{2}=10.5 \%$ for when FFF is not included in the equation. Furthermore, per regression results of Equation 19, the market rate of return is a significant predictor of $\mathrm{FFF}$ and $49.2 \%$ of variations of FFF is explained by variations of the market rate of return, $R^{2}=49.2 \%$. This implies there is a significant indirect effect of FFF on the relationship between market rate of return and companies' rates of return on equity, that is, change in FFF is a mediator in this relationship. This result is also confirmed by Preacher and Kelley's (2004) kappa-squared test results, $\kappa^{2}=0.033$, for the indirect effect, $95 \% \mathrm{BCa}$ CI [0.001, 0.078]. The CI for $\kappa^{2}$ does not contain 0 , so there is a mediation effect of FFF change on the relationship between market rate of return and companies' rates of return on equity.

\section{Conclusions and Implications of Findings}

In this study, we developed and tested a multifactor CAPM with the rate of return on company's equity as the dependent variable and changes in M2, FFR, and FFF as the independent variables while controlling for macro and firm-specific factors. The sample consisted of 30 large companies and 60 small companies randomly selected from the Russel 1000 and Russell 2000 Stock Index components, respectively. The sample time period was 2005-2015, and we applied regression methodologies suitable for panel data analysis to analyze the data.

In the pooled regression approach, we found market rate of return and company size as significant predictors of companies' rates of return on equity; supporting single-factor CAPM as well as Fama and French's (1992) propositions. In both the fixed- and random-effect approaches, the market rate of return and FFR (but not the monetary-policy-related independent variables) showed to be significant predictors of individual company's return on equity. Appealing results were, however, found in the modified pooled regression approach, where we treated the monetary-policy-related factors as moderator and mediator variables. 
We found a significant positive moderation effect of M2 on the relationship between market rate of return and companies' rates of return on equity, at all levels of M2. But, the strength of the relationship between market rate of return and rate of return on companies' equities increases as the percentage change in M2 increases and this relationship is not statistically significant when percentage change in M2 is low. These findings are in line with the work of other economists (Chen, 2007; Hamburner \& Kochin, 1972). However, there was no indirect effect of M2 on the relationship between market rate of return and companies' rates of return on equity; that is, M2 was not a mediator in this relationship. This implies that the market rate of return is not a significant predictor of the M2, meaning Fed decisions on changing M2 are not influenced by changes in the equity prices.

Regarding the FFR, the result indicated a significant negative moderation effect of change in the FFR on the relationship between market rate of return and companies' rates of return on equity. Moreover, we found that there is a positive relationship between market rate of return and rate of return on companies' equity at all levels of FFR. However, the strength of the relationship between market rate of return and rate of return on companies' equity decreases as the percentage change in the FFR increases and this relationship is statistically significant at all levels of the FFR changes. As for the mediation effect of FFR, we found a significant indirect effect of the FFR on the relationship between market rate of return and companies' rates of return on equity; that is, change in the FFR is a mediator in this relationship. This relationship was confirmed by some other economists (see Patelis, 1997; Thorbecke, 1997). This implies that the market rate of return is a significant predictor of the FFR; that is, the Fed policy decision on changing the FFR is influenced by changes in the equity prices. This can be interpreted as the fact that changes in the market rate of return are a signal for the Fed to adjust its decision on changing the FFR, indicating the mutual relationship between monetary policy and macro economy. This conclusion agrees with the fact that the Fed actually considers economic circumstances in their monetary policy decisions (Yellen, 2015).

As for the FFF, we found there is a significant negative moderation effect of change in FFF on the relationship between market rate of return and companies' rates of return on equity and that this relationship is significant at all levels of FFF. This finding is in line with those of Bernanke and Kuttner (2003). However, we found that in this moderation role the strength of the relationship between market rate of return and rate of return on companies' equity decreases as the percentage change in FFF increases. Regarding the mediation effect of FFF, we found that there is a significant indirect effect of FFF on the relationship between market rate of return and companies' rates of return on equity; that is, change in FFF is a mediator in this relationship. Moreover, the mediation analysis indicated that the market rate of return is a significant and strong predictor of $\mathrm{FFF}$, and $49.2 \%$ of variations of FFF is explained by variations of the market rate of return. It is notable that the significant relationship between FFF and companies' equities found in our research signals the importance of private sectors' expectations in equity price determination.

\section{Socioeconomic Implications of the Findings}

A change in Fed monetary policy does not have immediate direct effect on the economy; it affects the investors' expectation and equity prices first and then affects the macro variables in the economy. In other words, there is a lag between policy actions and target changes in the macroeconomy (see Chen, 2007). The monetary policy of the Fed affects the equity market as far as it changes the investors' expectations. Historical events support this conclusion, as in 2007-2008 crisis, despite the zero-bound territory policy, economic recession continued for quite a while because it could not raise the private sectors' expectations. In the fourth quarter of 2008 and the first quarter of 2009 , the global economic activity showed the weakest performance in decades (Bernanke, 2009). This shows that equity market is forward looking and supports the use of forward guidance policy by FOMC. 
Forward-leading policy of the Fed aims at improving the consumer sentiment and changing the investors' expectations in the equity market (see Bernanke, 2009; Engen et al., 2015).

FFF is the best indicator for future economic outlook and future trend of monetary policy, and it is the closest quantifiable indicator of the surprise component of the Fed's announcement. This makes FFF the strongest criterion that investors should use in their investment decision making (Bernanke \& Kuttner, 2003). The Fed considers economic outlook in its policy actions. In particular, it considers the market rate of return as a sign of the health in the economy, and the market rate of return is a signal to the Fed for its decision to change the FFR (Yellen, 2015).The fact that both FFR and federal fund futures show significant effects as mediators shows the mutual effect of interest rate changes and asset prices. This somewhat confirms the view of leaning against the wind (see Cecchetti et al, 2000; Gwilym, 2013; Greenspan, 2002).

\section{References}

Beck, N. (2001). Time-series-cross-section data. Statistica Neerlandica, 55, 111-133. doi:10.1111/1467-9574.00161

Berge, T. J., \& Guangve, C. (n.d). Global effect of U.S. monetary policy: Is unconventional policy different? Retrieved from http://citeseerx.ist.psu.edu/viewdoc/download?doi=10.1.1.655.4438\&rep=rep1\&type=pdf

Bernanke, B. S. (2009). The crisis and the policy response (Lecture). London School of Economics, London, England.

Bernanke, B. S., \& Blinder, A. S. (1992). The federal funds rate and the channels of monetary transmission. American Economic Review, 82, 901-921.

Bernanke, B. S., \& Gertler, M. (2001). Should central banks respond to movements in asset prices? American Economic Review 91, 253-257. doi:10.1257/aer.91.2.253

Bernanke, B. S., Gertler, M., \& Gilchrist, S. (1999). The financial accelerator in a quantitative business cycle framework. In J. B. Taylor \& M. Woodford (Eds.), Handbook of macroeconomics (pp. 1341-1393). Amsterdam, The Netherlands: Elsevier.

Bernanke, B. S., \& Kuttner, K. N. (2003). What explains the stock market's reaction to Federal Reserve policy? (Staff Report Number 174). Federal Reserve Bank of New York, New York, NY. Retrieved from https://www.newyorkfed.org/medialibrary/media/research/staff_reports/sr174.pdf

Blanchard, O. (2012). Monetary policy in the wake of the crisis. In O. Blanchard, D. Romer, M. Spence, \& J. Stiglitz (Eds.), Leading economists reassess economic policy (pp. 4-228). Cambridge, MA: MIT Press.

Blinder, A. S. (2010). How central should the central bank be? Journal of Economic Literature, 48, 123-133. doi:10.1257/jel.48.1.123

Brunner, A. D. (2000). On the derivation of monetary policy shocks: Should we throw the VAR out with the bath water? Journal of Money, Credit, and Banking, 32, 254-279. doi:10.2307/2601242

Cecchetti, S. G., Genberg, H., Lipsky, J., \& Wadhwani, S. B. (2000). Asset prices and central bank policy. London, United Kingdom: CEPR.

Chen, S. S. (2007). Does monetary policy have asymmetric effects on stock returns? Journal of Money, Credit and Banking, 39, 667-688. doi:10.1111/j.0022-2879.2007.00040.x 
Cook, T., \& Hahn, T. (1989). The effect of changes in the federal funds rate target on market interest rates in the 1970s. Journal of Monetary Economics, 24, 331-351. doi:10.1016/03043932(89)90025-1

Cooper, R. V. L. (1974). Efficient capital markets and the quantity theory of money. Journal of Finance, 29, 887-908. doi:10.1111/j.1540-6261.1974.tb01489.x

Doh, T. (2010). The efficacy of large-scale asset purchases at the zero lower bound. Federal Reserve Bank of Kansas City Economic Review, 2, 5-34.

Doh, T., \& Connolly, M. (2013). Has the effect of monetary policy announcements on asset prices changed? Kansas City, MO: Federal Reserve Bank of Kansas City. Retrieved from https://www.kansascityfed.org/publicat/econrev/pdf/13q3Doh-Connolly.pdf

Ehrmann, M., \& Fratzscher, M. (2004). Taking stock: Monetary policy transmission to equity markets. Journal of Money, Credit and Banking, 36, 719-737. doi:10.1353/mcb.2004.0063

Engen, E. M., Laubach, T., \& Reifschneider, D. (2015). The macroeconomic effects of the Federal Reserve's unconventional monetary policies (Finance and Economic Discussion Series 2015005). Washington, DC: Board of Governors of the Federal Reserve System. doi:10.17016/FEDS.2015.005

Fama, E. F., \& French, K. R. (1992). The cross-section of expected stock returns. The Journal of Finance, 47, 427-465.

Fama, E. F., \& French, K. R. (1993). Common risk factors in the returns of stocks and bounds. Journal of Financial Economics, 33, 3-56. doi:10.1016/0304-405X(93)90023-5

Fama, E. F., \& French, K. R. (1996). Multifactor explanation of asset pricing anomalies. Journal of Finance, 51, 55-84. doi:10.1111/j.1540-6261.1996.tb05202.x

Fama, E. F., \& French, K. R. (2004). The capital asset pricing model: Theory and evidence. The Journal of Economic Perspectives, 18, 25-46. doi:10.1257/0895330042162430

Field, A. (2013). Discovering statistics using IBM SPSS statistics. Los Angeles, CA: Sage.

G*Power. (2014). G*Power 3.1 manual. Retrieved from http://www.gpower.hhu.de/fileadmin/redaktion/Fakultaeten/MathematischNaturwissenschaftliche_Fakultaet/Psychologie/AAP/gpower/GPowerManual.pdf

Gagnon, J., Raskin, M., \& Remache, J., \& Sack, B. (2011). Large-scale asset purchases by the Federal Reserve: Did they work? International Journal of Central Banking, 7, 3-44. doi:10.2139/ssrn.1952095

Giannone, D., Lenza, M., Pill, H., \& Reichlin, L. (2011). Non-standard monetary policy measures and monetary developments. In J. S. Chadha \& S. Holly (Eds.), Interest rates, prices and liquidity: Lessons from the financial crisis (pp. 195-221). Cambridge, United Kingdom: Cambridge University Press. doi:10.1017/CBO9781139044233.008

Greenspan, A. (1995). The challenge of central banking in a democratic society: Annual dinner of the American Enterprise Institute for Public Policy Research. Retrieved April 4, 2013, from http://www.federalreserve.gov/ boarddocs/speeches/1996/19961205.htm

Greenspan, A. (2002). Opening remarks. Retrieved from http://kansascityfed.org/publicat/sympos/2002/pdf/S02Greenspan.pdf

Gürkaynak, R. S., Sack, B. P., \& Swanson, E. T. (2007). Market-based measures of monetary policy expectations. Journal of Business \& Economic Statistics, 25, 201-212. doi:10.1198/073500106000000387

Gwilym, R. A. (2013). The monetary policy implications of behavioral asset bubbles. Southern Economic Journal, 80, 252-270. doi:10.4284/0038-4038-2011.242 
Hamburner, M. J., \& Kochin, L. A. (1972). Money and stock prices: The channels of influences. Journal of Finance, 27, 231-249. doi:10.2307/2978472

Johnson, P. O., \& Neyman, J. (1936). Tests of certain linear hypotheses and their application to some educational problems. Statistical Research Memoirs, 1, 57-93.

Krishnamurthy, A., \& Vissing-Jorgenson, A. (2011). The effects of quantitative easing on long-term interest rates. Brookings Papers on Economic Activity, 2, 215-265. doi:10.1353/eca.2011.0019

Krueger, J. T., \& Kuttner, K. (1996). The Fed funds futures rate as a predictor of Federal Reserve policy. Journal of Futures Markets, 16, 865-879. doi:10.1002/(SICI)10969934(199612)16:8<865::AID-FUT2>3.0.CO;2-K

Kuttner, K. N. (2000). Monetary policy surprises and interest rates: Evidence from the fed funds futures market (Staff Report Number 99). Federal Reserve Bank of New York, New York, NY

Kuttner, K. N. (2001). Monetary policy surprises and interest rates: Evidence from the fed funds futures market. Journal of Monetary Economics, 47, 523-544. doi:10.1016/S03043932(01)00055-1

Lenza, M. P. H., \& Reichlin, L. (2010). Monetary policy in exceptional times. Economic Policy, 25, 295-339. doi:10.1111/j.1468-0327.2010.00240.x

Linter, J. (1965). The valuation of risky assets and the selection of risky investments in stock portfolios and capital budgets. Review of Economics and Statistics, 47, 13-37. doi:10.2307/1924119

Markowitz, H. (1952). Portfolio selection. The Journal of Finance, 7, 77-91.

Meaning, J., \& Zhu, F. (2011). The impact of recent central bank asset purchase programs. BIS Quarterly Review, 20, 73-83. doi:10.1111/j.1540-6261.1952.tb01525.x

Mossin, J. (1966). Equilibrium in a capital asset market. Econometrica, 34, 768-784. doi:10.2307/1910098

Neely, C. (2010). The large-scale asset purchases had large international effects (Working Paper Number 18A). Federal Reserve Bank of Saint Louis, Saint Louis, MO.

Patelis, A. D. (1997). Stock return predictability and the role of monetary policy. Journal of Finance, 52, 1951-1972. doi:10.1111/j.1540-6261.1997.tb02747.x

Perez-Quiros, G., \& Timmermann, A. (2000). Firm size and cyclical variations in stock returns. Journal of Finance, 55, 1229-1262. doi:10.1111/0022-1082.00246

Pesando, J. E. (1974). The supply of money and common stock prices: Further observations on the econometric evidence. Journal of Finance, 29, 909-921. doi:10.1111/j.15406261.1974.tb01490.x

Preacher, K. J., \& Hayes, A. F. (2004). SPSS and SAS procedures for estimating indirect effects in simple mediation models. Behavior Research Methods, Instruments, \& Computers, 36, 717731. Retrieved from http://quantpsy.org/pubs/preacher_hayes_2004.pdf

Rigobon, R., \& Sack, B. (2003). Measuring the reaction of monetary policy to the stock market. Quarterly Journal of Economics, 118, 639-669. doi:10.1162/003355303321675473

Rogalski, R. J., \& Vinso, J. D. (1977). Stock returns, money supply and the direction of causality. Journal of Finance, 32, 1017-1030. doi:10.1111/j.1540-6261.1977.tb03306.x

Rogers, J. H., Scotti, C., \& Wright, J. H. (2014). Evaluating asset-market effects of unconventional monetary policy: A cross-country comparison (Discussion Paper Number 1101). Board of Governors of the Federal Reserve System International Finance, Washington, DC. doi:10.2139/ssrn.2420387 
Rosa, C. (2012). How unconventional are large-scale asset purchases? The impact of monetary policy on asset prices (Staff Report Number 560). Federal Reserve Bank of New York, New York, NY. doi:10.2139/ssrn.2053640

Rudebusch, G. (1998). Do measures of monetary policy in a VAR make sense? International Economic Review, 39, 907-931. doi:10.2307/2527344

Swanson, E. T. (2011). Let's twist again: A high frequency event study analysis of operation twist and its implications for QE2. Brookings Papers on Economic Activity, 2011, 151-188. doi:10.1353/eca.2011.0006

Thorbecke, W. (1997). On stock market returns and monetary policy. Journal of Finance, 52, 635654. doi:10.1111/j.1540-6261.1997.tb04816.x

Woodford, M. (2012). Methods of policy accommodation at the interest-rate lower bound. Retrieved from https://www.kansascityfed.org/publicat/sympos/2012/mw.pdf

Wright, J. H. (2012). What does monetary policy do at the zero lower bound? Economic Journal, 122, 447-466. doi:10.1111/j.1468-0297.2012.02556.x

Yellen, J. (2015, March 27). Normalizing monetary policy: Prospects and perspectives. Presented at The New Normal Monetary Policy, a research conference sponsored by the Federal Reserve Bank of San Francisco, San Francisco, CA. Retrieved from https://www.federalreserve.gov/newsevents/speech/yellen20150327a.htm

The International Journal of Applied Management and Technology (IJAMT), sponsored by Walden University's School of Management, is a peer-reviewed, online journal that addresses contemporary national and international issues related to management and technology. The objectives of the IJAMT are to: (a) encourage collaborative and multi-disciplinary examinations of important issues in business and technology management, and (B) engage scholars and scholar-practitioners in a dynamic and important dialogue.

Walden University Publishing: http://www.publishing.waldenu.edu 